\title{
Horizontal Distribution of Benthic Macroinvertebrates in Lake Kizaki, Japan
}

\author{
Kimio Hirabayashi and Hidetake Hayashi
}

\begin{abstract}
The distribution of benthic macroinvertebrates was studied in November 1985 in Lake Kizaki (maximum depth : $29.5 \mathrm{~m}$ ). The average biomass of the benthic community comprised oligochaetes ( $7.7 \%)$, chaoborids $(44.9 \%)$ and chironomids $(47.4 \%)$. The oligochaetes inhabited the entire lake bottom, with higher densities in the shallower regions $(<10 \mathrm{~m})$. In contrast, densities of chaoborid larvae were higher in the deeper regions $(>20 \mathrm{~m})$ than in the shallower regions. Chironomid larvae, on the other hand, were distributed in higher populations in the transitional regions $(10-20 \mathrm{~m})$, and a marked decline in the number of species was observed as the depth increased. The most abundant species was $C$. nipponensis which was distributed most widely from $2 \mathrm{~m}$ to $27 \mathrm{~m}$, although the density was very low at depths of $20 \mathrm{~m}$ or more due to the lack of dissolved oxygen. In the deeper regions, the dominant species of chironomid had changed from Endochironomus sp. in the 1930's to C. nipponensis in the present study. It is suggested that the environmental conditions for larval survival in deeper regions will continue to deteriorate.
\end{abstract}

Key words: benthic macroinvertebrates, horizontal distribution, dissolved oxygen concentration, Lake Kizaki

\section{Introduction}

The biota of Lake Kizaki has been studied by many workers since TanaKa (1930). However, studies of benthic macroinvertebrates have been very few (Miyadi, 1931; KitAGawa, 1973; Asakawa, 1977, 1978, 1980), because of the difficulty of species identification.

From the end of the 1970s to the end of 1980 s, the biota and the environmental conditions of the lake changed drastically (НАYASHI, 1990), and this must have had some effect on the bottom fauna, especially on the dominant chironomids.

This paper deals with the distribution of chironomid larvae, chaoborid larvae and the oligochaetes in Lake Kizaki, and discusses the succession of benthic macroinvertebrates in relation to the change in the lake's environment.

\section{Study site}

Lake Kizaki is located at the eastern foot of the Japanese Northern Alps along the tectonic zone or Fossa Magna which traverses the main island (Honshu) of Japan $\left(36^{\circ} 33^{\prime} \mathrm{N}, 137^{\circ} 50^{\prime} \mathrm{E}\right.$ at the center of the lake; surface area $1.4 \mathrm{~km}^{2}$; maximum depth $29.5 \mathrm{~m}$; mean depth $17.9 \mathrm{~m}$; altitude above sea level $764 \mathrm{~m}$ ). There are three main inflowing rivers: the Naka-Nougu, Inaozawa, and Nishi, while the Shimo-Nougu is the only river flowing out of the lake's southern end (Fig. 1). The lake's eastern shore is partly surrounded by cultivated land. Villages occupy its northwestern and southern shores. This lake is ice-covered from January to February with a persistent thermocline in summer.

Many limnological studies have been carried out since the first major work by TANAKA (1930). Transparency averaged about $5 \mathrm{~m}$ until 1950 (SAIJo et al., 1983), but had decreased to approx- 
imately $3 \mathrm{~m}$ by 1970 (Hayashi, 1989). Since the end of the 1970's, Anabaena has bloomed annually in July-August (WatanaBe et al., 1985), and the coloration of surface water has also risen in frequency due to an increase in the abundance of microorganisms which graze upon Anabaena (Funakoshi et al., 1983; Hayashi, 1985). In the autumn of 1987, the dinoflagellate Peridinium grew explosively, forming a freshwater red tide (KidA et. al., 1989 ; PARK and HayAshi, 1992).

AIZAKI et al. (1981) ranked this lake as a mesotrophic one, using the modified Carlson's trophic state index based on chlorophyll-a, total phosphorus, and transparency.

\section{Materials and methods}

\section{3-1. Collection of benthic macro- invertebrates}

Yamagishi and Fukuhara (1972), and Iwakuma and YASUNo (1981) reported that the larvae of Tokunagayusurika akamusi burrowed deep into the sediment to estivate during the summer. Benthic macroinvertebrates can be gathered most efficiently from late autumn to early spring, when almost all larvae, especially $T$. akamusi, come close to the surface of the sediment. On 11 November, 1985, a multi-point sampling survey was carried out using a standard Ekman-Birge grab $(15 \times 15 \mathrm{~cm})$, taking three replicate samples at each of 32 locations $(2.1 \sim 29.1 \mathrm{~m})$ in a $250 \times 250 \mathrm{~m}$ grid (Fig. 1). After sieving the sediment through a Surber net (NGG $38 ; 560 \mu \mathrm{m}$ mesh size), benthic macroinvertebrates (chironomid larvae, chaoborid larvae and oligochaetes) were picked up and counted in the laboratory. The first and second instar larvae of small chironomids were not retained by the $560 \mu \mathrm{m}$ sieve.

To identify chironomids, some larvae were soaked in a $10 \% \mathrm{KOH}$ solution, mounted on slides with gum-chloral solution and examined under a microscope. The identification was made to the generic level according to the keys of Wiederholm (1983) and Cranston (1982).

\section{3-2. Physical environmental factors}

Bottom sediment samples for an organic matter analysis were collected with a core sampler (3cm inner diameter). Mud in the upper

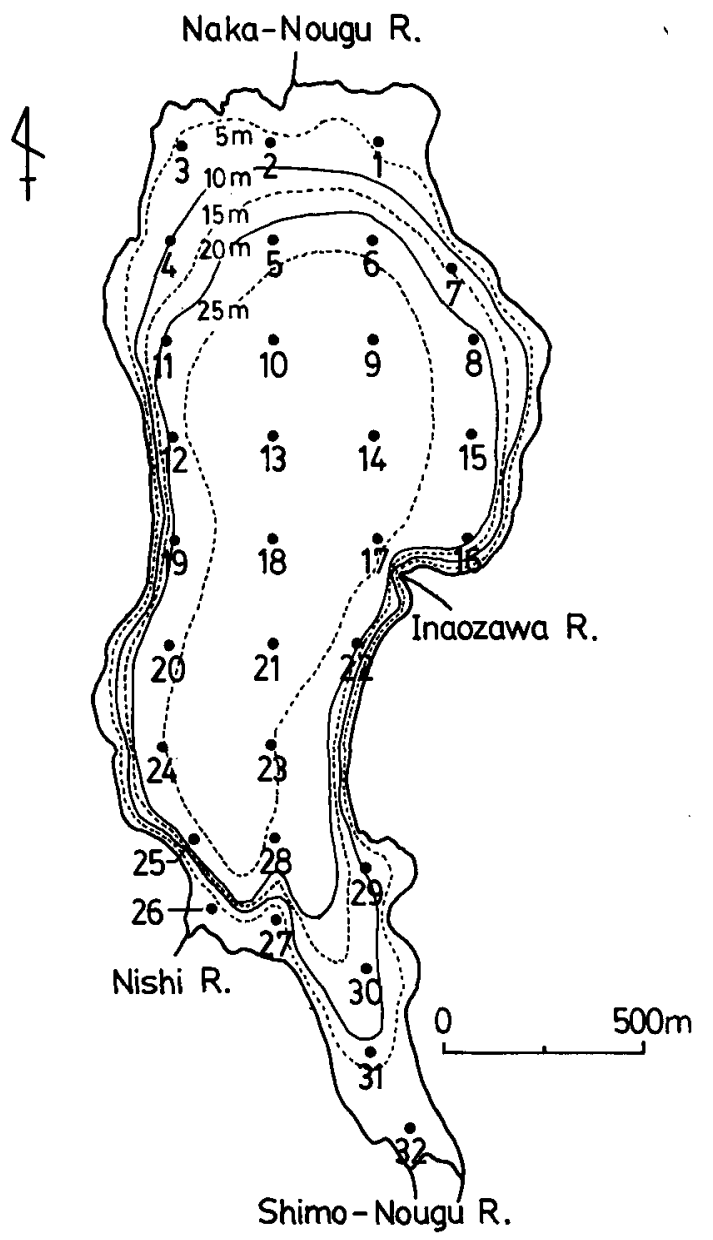

Fig. 1. Map showing sampling stations in Lake Kizaki.

$3 \mathrm{~cm}$ layer of each core was oven-dried at $110^{\circ} \mathrm{C}$ for two days and ignited in a muffle furnace at $500^{\circ} \mathrm{C}$ for two hours to determine the values of loss on ignition.

The water temperature was measured on the bottom sediments with a thermistor thermometer (Toho Dentan, ET-5).

We used a core sampler to measure dissolved oxygen concentrations in the water at the mud -water interface. The water near the bottom of the core sampler was siphoned carefully into a glass bottle. The dissolved oxygen concentration was determined by Winkler's method with azide modification. 
Table 1. Mean values and standard deviations of the variables reperesenting environmental factors in the multi-point sampling survey in November 1985.

\begin{tabular}{|c|c|c|c|c|}
\hline Environmental factors & $<10 \mathrm{~m}$ & $10-20 \mathrm{~m}$ & $>20 \mathrm{~m}$ & Total \\
\hline Number of sampling points & 7 & 4 & 21 & 32 \\
\hline Depth $(\mathrm{m})$ & $4.2 \pm 1.4$ & $12.0 \pm 1.6$ & $24.9 \pm 2.8$ & $18.8 \pm 9.1$ \\
\hline Loss on ignition (\%) & $6.9 \pm 5.4$ & $10.9 \pm 1.0$ & $12.0 \pm 1.5$ & $10.7 \pm 3.5$ \\
\hline \multirow[t]{2}{*}{ Water temperature $\left({ }^{\circ} \mathrm{C}\right)$} & $10.2 \pm 0.5$ & $10.4 \pm 0.6$ & $6.2 \pm 0.3$ & $7.6 \pm 2.0$ \\
\hline & L & & 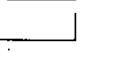 & \\
\hline Dissolved oxygen $\left(\mathrm{mg} \cdot \mathrm{l}^{-1}\right)$ & $9.9 \pm 0.3$ & $9.4 \pm 0.2$ & $0.4 \pm 0.3$ & $3.4 \pm 4.4$ \\
\hline
\end{tabular}

$*$ : Difference is significant $(P<0.05)$.

\section{3-3. Survival of chironomid larvae under anaerobic conditions}

A comparative study was made on the tolerance to anaerobic conditions of chironomid larvae (Chironomus nipponensis and Phaenop. sectra kizakiensis). Fourth instar larvae were used in all cases. The time of survival without oxygen was measured by keeping the larvae in bottles containing nitrogen-saturated water $(<$ $\left.0.2 \mathrm{mg} \mathrm{O}{ }_{2} \cdot 1^{-1}\right)$, which were then kept submerged in a water bath $\left(16^{\circ} \mathrm{C}\right)$ in the dark. The number of dead individuals which did not build the nest was counted at intervals. In all cases larvae were enclosed in the proportion of $30 \mathrm{mg}$. d.w. to $100 \mathrm{ml}$. water: the number of animals varied from 8 to 14 per bottle according to the size of the larvae. Five replicate bottles were checked for each species.

\section{Results}

\section{4-1. Environmental factors}

The results of environmental factor analysis are shown in Table 1. In this paper, based on environmental factor observations, the lake area was roughly divided into three regions: the shallower region $(<10 \mathrm{~m})$, the transitional region $(10-20 \mathrm{~m})$ and the deeper region $(>20 \mathrm{~m})$.

\section{4-1-1. Loss on ignition of sediment}

The values of loss on ignition of the upper $3 \mathrm{~cm}$ of the sediment taken from 32 locations ranged from $1.5 \%$ (sand) to $18.6 \%$ (mud). Most of the lake basin consisted of soft bottom with organic matter contents higher than $10 \%$.
Sediments at Sta. 1 contained the highest levels of organic matter $(18.6 \%)$ of all the stations.

In regions shallower than $10 \mathrm{~m}$, i.e., at Sta. 2 (mouth of the Naka-Nougu River), Sta. 17 (mouth of the Inaozawa River), Sta. 26 (mouth of the Nishi River), Stas. 27, 31, and 32 (southern outlet of the lake), the sediments were generally sandy with low values of loss on ignition $(1.5-8.1 \%)$. In regions deeper than $10 \mathrm{~m}$, i.e., at Stas. 10,13 and 14 , the bottom sediments consisted mainly of mud with relatively high values of loss on iginition (12.0 $14.0 \%$ ).

\section{4-1-2. Bottom water temperature}

The bottom water temperature ranged from 5.8 (Sta. 14) to $11.1^{\circ} \mathrm{C}$ (Sta. 31). In regions shallower than $20 \mathrm{~m}$, i.e., at Stas. $1 \sim 4,7$ (northern part of the lake) and 26, 27, 29 32 (southern part), the bottom water temperatures were over $10^{\circ} \mathrm{C}$. In regions deeper than $20 \mathrm{~m}$, they were below $6.5^{\circ} \mathrm{C}$. The difference was significant between $<10 \mathrm{~m}$ and $>20 \mathrm{~m}$, and $10-20 \mathrm{~m}$ and $>20$ m (Mann-Whitney's U-test).

\section{4-1-3. Dissolved oxygen concentration}

The dissolved oxygen concentrations in bottom water ranged from 0.0 to $10.2 \mathrm{mg} \cdot 1^{-1}$. In regions shallower than $20 \mathrm{~m}$, the dissolved oxygen concentrations were over $9.0 \mathrm{mg} \cdot 1^{-1}$, and in regions deeper than $20 \mathrm{~m}$, they were below $1.0 \mathrm{mg} \cdot 1^{-1}$. There was a significant difference between $<10 \mathrm{~m}$ and $>20 \mathrm{~m},<10 \mathrm{~m}$ and $10-20 \mathrm{~m}$, and $10-20 \mathrm{~m}$ and $>20 \mathrm{~m}$ (Mann-Whitney's $U$ -test). 
Table 2. Mean values and standard deviations of the densities of benthic macroinvertebrates in 1985 .

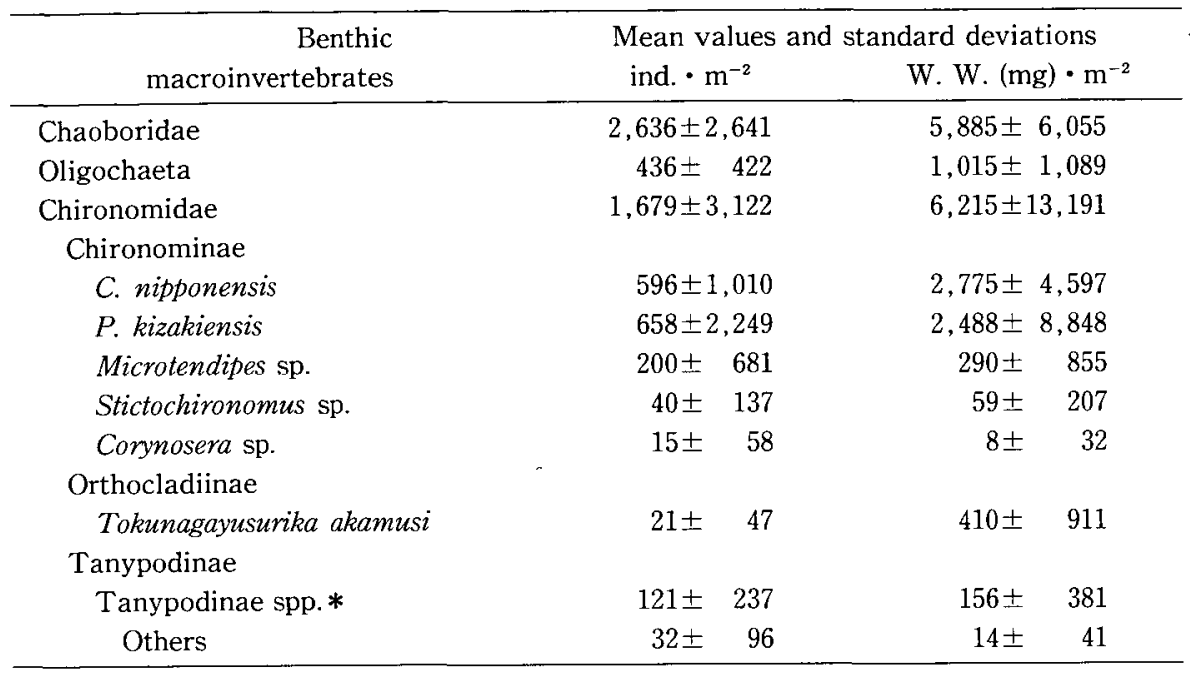

* includes 2 genera

\section{4-2. The distribution of benthic macroinvertebrates}

Table 2 shows the mean values with standard deviations of the variables representing benthic macroinvertebrates, chironomid and chaoborid larvae, and oligochaetes. The average densities of chironomid and chaoborid larvae and oligochaetes for all the stations were $1,679 \pm 3,122$ (35.3\%), 2,636 $\pm 2,641$ (55.5\%) and $436 \pm 422$ $(9.2 \%)$ ind. $\cdot \mathrm{m}^{-2}$, respectively. On the other hand, the average biomass (wet weight) of these benthic macroinvertebrates were $6,215 \pm 13,191$ $(47.4 \%), 5,885 \pm 6,055(44.9 \%)$ and $1,015 \pm 1,089$ (7.7\%) $\mathrm{mg} \cdot \mathrm{m}^{-2}$, respectively. Among Chironomidae, five species belonged to the subfamily Chironominae, one species to Orthocladiinae, and two genera to Tanypodinae. The predominant species of chironomid was $C$. nipponensis. The larvae of this species were the largest in size, and thus constituted a major portion of the total biomass of chironomid larvae in this lake.

Figure 2 shows the density of some benthic macroinvertebrates (Chaoborus, Oligochaeta, $C$. nipponensis, $P$. kizakiensis, Tanypodinae spp. and T. akamusi) in relation to water depth, while Figure 3 shows the horizontal distributions of some benthic macroinvertebrates. Chaoborid larvae were found at almost all stations. The population density was low in the shallower regions and high in the deeper regions. Oligochaetes also inhabited the entire lake bottom, with higher densities in the shallower and transitional regions. The population density of chironomid larvae differed among the sampling stations, being very low near the center of the lake and reaching a maximum $\left(16,000\right.$ ind. $\left.\cdot \mathrm{m}^{-2}\right)$ on the northeastern side of the lake.

The most abundant species, $C$. nipponensis, had the widest distribution (from $2.0 \mathrm{~m}$ to $27.0 \mathrm{~m}$ in depth) with high densities in the $10-20 \mathrm{~m}$ regions, and low densities at depths of $25 \mathrm{~m}$ and more. It was particularly abundant in the northeastern and southern parts of the lake (the maximum number of larvae reached 4,600 ind. $\mathrm{m}^{-2}$ at Sta. 8 ; depth, $\left.21.7 \mathrm{~m}\right)$. P. kizakiensis was also widely distributed, although the density was very low in regions shallower than $10 \mathrm{~m}$ and deeper than $20 \mathrm{~m}$ depth. The larval density was about 3.5 times higher than that of $C$. nipponensis in the transitional regions. The larvae of this species were numerous at the northern and southern stations. Microtendipes sp. and Stictochironomus sp. were found along the southern shore. The biomasses of these species were very small. $T$. akamusi was 

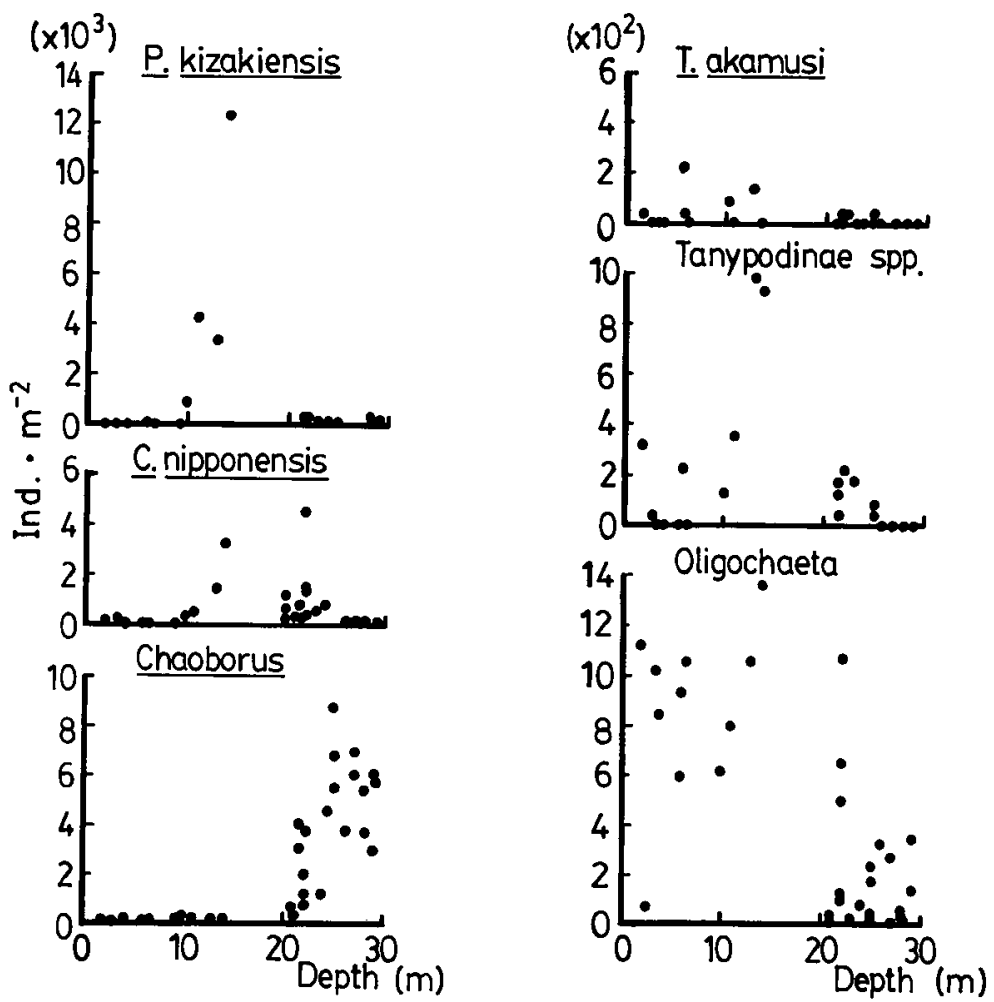

Fig. 2. Bathymetrical distribution of main benthic macroinvertebrates in Lake Kizaki.

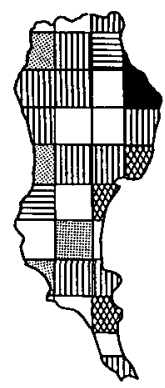

Chirononus nipponensis

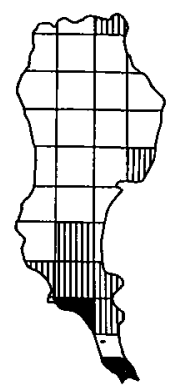

Microtendipes sp.

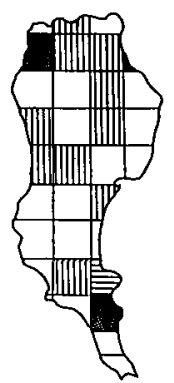

Phaenopsectra kizakiensis

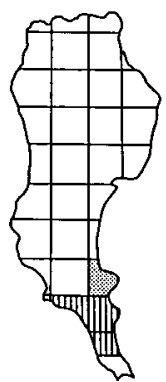

Stictochlronomus sp.

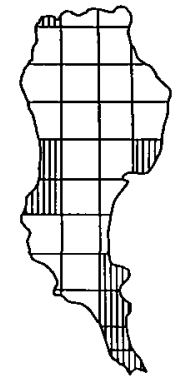

Tokunagayusurika akamus l

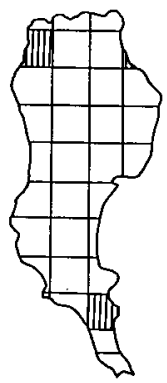

Corynocera sp.

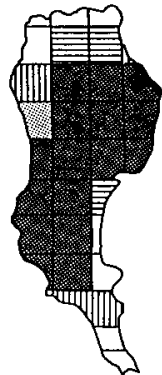

Chaoborus

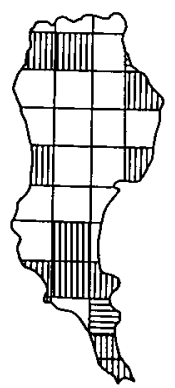

Tanypodinae spp.

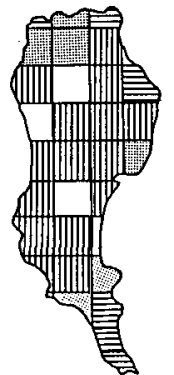

01 igochaeta

I n d. $\cdot \mathrm{m}^{-2}$

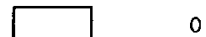

血监 $1-450$

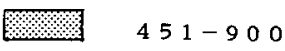

$901-1350$

$1351-1800$

\% $1800<$

Fig. 3. Horizontal distribution of chironomid larvae, chaoborid larvae and Oligochaetes in Lake Kizaki, November 1985. 
numerous at the northern stations near an inlet of domestic waste water (Sta. 3) and in the south near some hotels (Stas. 29, 30, 31, 32).

Table 3 shows the correlation matrix for variables in the number of benthic macroinvertebrates (chaoborid larvae; Cha, oligochaetes; Oli, C. nipponensis; C. n. and P. kizakiensis ; P. k.) as well as such environmental factors as depth, dissolved oxygen concentration (DO), water temperature (WT), and loss on ignition (LOI). Four environmental factors were closely related to each other. The density of Cha was closely related to the water depth, whereas that of Oli was closely related to DO and WT. The density of Cha-DO, Cha-WT and Cha-Oli, and the density of Oli-depth showed negative correlations. The density of $C . n$. was closely related to P. k., The density of P. k. was closely related to Oli and DO.

\section{4-3. Survival of larvae under anaerobic conditions}

The data on survival of larvae, $C$. nipponensis and $P$. kizakiensis, under anaerobic conditions are given in Figure 4. C. nipponensis and $P$. kizakiensis differed strikingly in their survival under anaerobic conditions. P. kizakiensis had a low survival rate. The larvae ceased to show respiratory undulation after 20 to $30 \mathrm{hr}$, and $50 \%$ of them died after from 30 to $40 \mathrm{hr}$. On the other hand, $C$. nipponensis larvae remained alive longer.

Table 3. Correlation matrix for environmental variables and densities of benthic macroinvertebrates.

\begin{tabular}{|c|c|c|c|c|c|c|c|}
\hline & DO & WT & LOI & Cha & Oli & C. $n$. & P. k. \\
\hline Depth & $-0.948^{* *}$ & $-0.930^{* *}$ & $0.560^{* *}$ & $0.771^{* *}$ & $-0.688^{* *}$ & -0.043 & -0.404 \\
\hline DO & & $0.987^{* *}$ & $-0.693^{* *}$ & $-0.723^{* *}$ & $0.724^{* *}$ & -0.007 & $0.388^{*}$ \\
\hline WT & & & $-0.548^{* *}$ & $-0.730^{* *}$ & $0.738^{* *}$ & -0.011 & 0.336 \\
\hline LOI & & & & $0.366^{*}$ & -0.275 & 0.205 & 0.082 \\
\hline Cha & & & & & $-0.544^{* *}$ & -0.097 & -0.267 \\
\hline Oli & & & & & & $0.421^{*}$ & $0.494^{* * *}$ \\
\hline C. $n$. & & & & & & & $0.493^{* *}$ \\
\hline
\end{tabular}

DO; dissolved oxygen, WT; water temperature, LOI; loss on ignition, Cha ; chaoborid larvae, Oli ; oligochaetes, C. n. ; C. nipponensis, P. k. ; P. kizakiensis

*Significant at 0.05 probability level $(f=31)$

**Significant at 0.01 probability level $(f=31)$

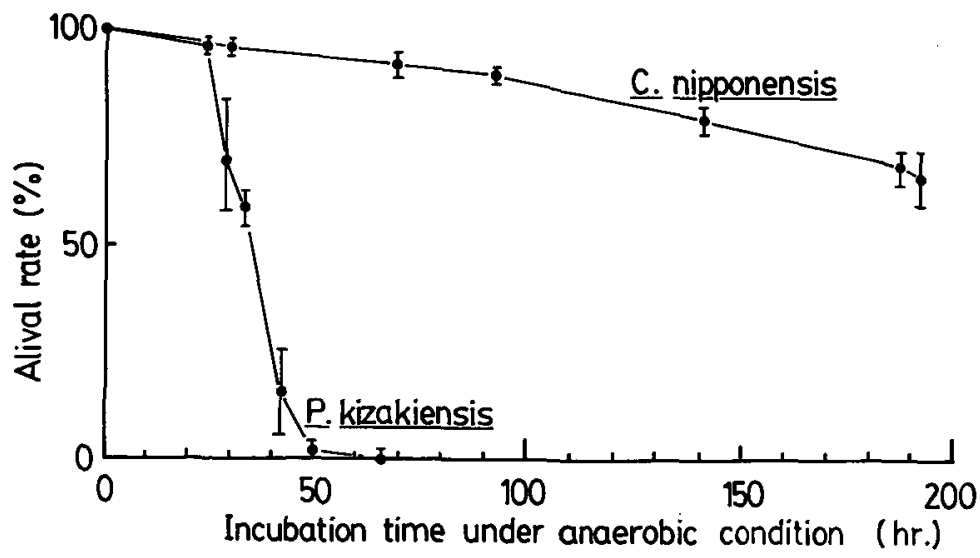

Fig. 4. Anaerobic resistance of $C$. nipponensis and $P$. kizakiensis larvae. Vertical bars indicate standard deviations. 


\section{Discussion}

Many studies have been conducted on the distribution of benthic macroinvertebrate populations in relation to various environmental factors (reviewed by JONASSON, 1972 ; BRINKHURST, 1974). According to Yasuno et al. (1984), the oxygen concentration is of primary importance in determining the distribution of benthic macroinvertebrates.

In Lake Kizaki, the density of chaoborid larvae showed a negative correlation with the dissolved oxygen concentration, whereas that of oligochaetes showed a positive correlation. This suggests the strong possibility that their distributions were regulated by the dissolved oxygen concentration. On the other hand, that of chironomid larvae did not clearly show a significant correlation with the oxygen concentration. Thus, P. kizakiensis had a weak correlation with the oxygen concentration, and $C$. nipponensis did not show a significant relationship to it (Table 3). There were fewer larvae in the shallower regions. However, the density of chironomid larvae was very low at depths of 25 $\mathrm{m}$ or more due to the lack of dissolved oxygen concentration (Fig. 2). These facts suggest that the distribution of chironomid larvae is not determined only by the dissolved oxygen concentration, although that might be an important factor in determining distribution of chironomid larvae. As compared with P. kizakiensis, C. nipponensis was distributed in the deeper region with a low dissolved oxygen concentration. This fact served to confirm that $C$. nipponensis was more tolerant than $P$. kizakiensis under anaerobic conditions in the laboratory experiment (Fig. 4).

Many researchers have used the distribution patterns of benthic macroinvertebrates, paticularly those in profundal zones, as indicators of trophic state and pollution (e.g. IWAKuma et al., 1988). BRINKHURST (1970) reviewed the distribution of tubificid oligochaetes in relation to organic pollution and pointed out they could be used as an indicator of pollution. According to CANNIngs and Scudder (1978), the relationship between the chironomid community and lake type stems from differences in tolerance to oxygen deficiency among various species.

In Japan, trophic classifications of lakes were made using chironomid fauna and chaoborid by MiYadi (1933) and KITAGAWA (1978), and modified by YASUNo et al. (1983) who pointed out that MrYaDI may have misidentified C. nipponensis as Chironomus plumosus. Yasuno et al. (1983) also reported that lakes where $C$. nipponensis are dominant may be classified as meso-middle (between eutrophic and mesotrophic).

We compared our results with those of Miyadi (1931) and Kitagawa (1973), and tried to clarify the relationship between the eutrophication of this lake and the dominant species of chironomids. Table 4 shows the distributions of dominant chironomid species according to water depth, based on the data of Miyadr (1931) and Kitagawa (1973). Miyadi (1931) reported that Endochironomus sp. was found at depths over $10 \mathrm{~m}$, the maximum being 16,380 ind $\cdot \mathrm{m}^{-2}$ at $21 \mathrm{~m}$. According to Kitagawa's (1973) description, C. plumosus-b was found over a relatively wide range of depths from $6 \mathrm{~m}$ to 28 $\mathrm{m}$. Moreover, he also found that the density of Endochironomus larvae, which seemed to be identical with Phaenopsectra, was low and that C. plumosus-b not recorded by MiYadi was found abundantly.

YASUNO et al. (1984) reported the possibility of C. nipponensis which Kitagawa (1974) described as $C$. plumosus-b based on their size, distribution and the details in his sketch. In our survey, C. nipponensis was the most abundant species of chironomid larvae year round, and larvae of C. plumosus and C. nipponensis are not likely to be found together since $C$. plumosus adults were never caught with a light trap or a net at any time during the year (HIRABAYASH, unpublished data). One important difference between our results and KITAGAWA's is that $C$. nipponensis were not found even in the deeper regions $(>28 \mathrm{~m})$.

According to SASA (1984), P. kizakiensis was described by ToKunaga (1940) with the name Pentapedilum kizakiensis based on male and female reared from larvae abundantly collected from the bottom of Lake Kizaki. TокUnAGA 
Table 4. Change in dominant chironomid fauna and their depth distribution in Lake Kizaki.

\begin{tabular}{|c|c|c|c|c|c|c|}
\hline $\begin{array}{l}\text { Study year } \\
\text { (literature) }\end{array}$ & $\begin{array}{l}\text { Dominant } \\
\text { species }\end{array}$ & $2 \mathrm{~m}$ & $6 \mathrm{~m}$ & $\begin{array}{c}10 \mathrm{~m} \\
\text { ind. } \cdot \mathrm{m}^{-2}\end{array}$ & $25 \mathrm{~m}$ & $28 \mathrm{~m}$ \\
\hline 1929 & Endochironomus sp. & & & & & \\
\hline \multirow[t]{2}{*}{ (MIYADI, 1931) } & No. & 0 & 0 & 156 & 5,044 & 1,508 \\
\hline & $\%$ & 0 & 0 & 5 & 100 & 100 \\
\hline 1972 & Chironomus plumosus-b & & & & & \\
\hline \multirow{5}{*}{ (Kitagawa, 1973) } & No. & & 90 & 225 & 45 & 45 \\
\hline & $\%$ & & 100 & 25 & 100 & 100 \\
\hline & Phaenopsectra sp. & & & & & \\
\hline & No. & & 0 & 45 & 0 & 0 \\
\hline & $\%$ & & 0 & 5 & 0 & 0 \\
\hline 1986 & Chironomus nipponensis & & & & & \\
\hline \multirow[t]{5}{*}{ (This study) } & No. & 444 & 267 & 889 & 489 & 0 \\
\hline & $\%$ & 13 & 29 & 43 & 100 & 0 \\
\hline & Phaenopsectra kizakiensis & & & & & \\
\hline & No. & 0 & 0 & 1,156 & 0 & 0 \\
\hline & $\%$ & 0 & 0 & 57 & 0 & 0 \\
\hline
\end{tabular}

(1940) stated that the immature stages of this species had been incorrectly reported in limnological papers as Endochironomus larvae. If the species described by MiYadi (1931) as Endochironomus sp. was $P$. kizakiensis, the larval distribution pattern of this chironomid had changed since Mryadr's study. In 1929, the larvae of $P$. kizakiensis was distributed from $10 \mathrm{~m}$ to $27.5 \mathrm{~m}$. In contrast, by 1972 this larvae was found in shallower regions, and was not found at all in the deeper regions $(>20 \mathrm{~m})$. The present study showed the same results as those in 1972.

Assuming that a species described by MIYADI (1931) as Endochironomus sp. was P. kizakiensis, and that Kitagawa (1974) erroneously identified C. nipponensis as C. plumosus-b, large environmental changes must have affected chironomid fauna, especially in the deeper regions with low dissolved oxygen concentrations $(>28 \mathrm{~m})$. Consequently, the distribution pattern of chironomids in the lake has changed.

The eutrophication of this lake is proceeding. It seems that favorable environmental conditions for larvae in deeper regions are deteriorating, and that larval distribution is shifting to regions shallower than $28 \mathrm{~m}$. Although this lake was classified as mesotrophic in previous studies (Aızakı et al., 1981 and others), we think this needs to be reconsidered in light of the circumstances mentioned above.

\section{Acknowledgements}

We are grateful to Dr. T. Iwakuma, and Dr. M. YASuNO of the Environmental Biology Division, National Institute for Environmental Studies for their helpful suggestions, observations, and critical reading of the manuscript. We also wish to express our thanks to the members of the Laboratory of Ecology, Faculty of Science, Shinshu University for their assistance during the course of this survey.

\section{摘要}

\section{木崎湖における大型底生無脊椎動物の 水平分布について}

1985 年 11 月, 木崎湖に扔いて大型底生無脊椎 動物の分布調査を行った。採集された底生動物は, 生物量で水生貧毛類が $7.7 \%$, フサカ幼虫が $44.9 \%$ ，コスリカ幼虫が $47.4 \%$ あった。水生負 毛類は, 湖全体で採集され, 特に $10 \mathrm{~m}$ 上り浅い地 点で多く採集された。これとは逆に, フサカ幼虫 は $20 \mathrm{~m}$ 以深の深い地点で多く採集された。一方, ユスリカ幼虫は 10-20 $\mathrm{m}$ の深さの地点で多く採 集され，深さが増すに従って捕獲個体数，ならび 
に種類数が減少する傾向がみられた。最も多く採 集されたユスリカ幼虫は C. nipponensis で，2-27 $\mathrm{m}$ と広い範囲で分布した。しかしながら，底層の 溶存酸素が久乏する $20 \mathrm{~m}$ 以深の地点では生息数 が極めて少なく，過去のデータとの比較から，工 スリカ幼虫の優占種が Endochironomus sp. (P. kizakiensis と思われる)からC. nipponensis に変 化していることが明らかとなった。このことは， 現在の木崎湖の深底部環境が, 1930 年代に比べ, 大きく変化していることを示していると思われ た。

\section{References}

Aizaki, M., Otsuki, A., Fukushima, T., Kawai, T., Hosomi, M. and Muraoka, K. (1981): Application of modified Carlson's trophic state index to Japanese lake and its relationships to other parameters related to trophic state. Res. Rep. Natl. Inst. Environ. Stud. Jpn., 23 : 13-31 (in Japanese with English summary).

Asakawa, F. (1977): The studies of Chironomidae (Diptera) in Nishina-sanko. Kita-Azumi-Kyoiku, 23 : 1-9 (in Japanese).

Asakawa, F. (1978): The studies of Chironomidae (Diptera) in Nagano prefecture (I). Shinano -Kyoiku, 1103: 1-13 (in Japanese).

Asakawa, F. (1980): The studies of Chironomidae (Diptera) in Nishina-sanko (II). Kita-Azumi -Kyoiku, 26 : 1-9 (in Japanese).

BRINkHURST, R. O. (1970) : Distribution and abundance of tubificid (Oligochaeta) species in Toronto Harbour, Lake Ontario. J. Fish. Res. Bd. Canada, 27 : 1961-1969.

Brinkhurst, R. O. (1974): The benthos of Lakes. The Macmillan Press ltd.. Cannings, R. A. and Scudder, G. G. E. (1978): The littoral chironomidae (Diptera) of saline lakes in central British Columbia. Can. J. Zoo., 56 : 1144-1155.

Cranston, P. S. (1982): A key to the larvae of the British Orthocladinnae (Chironomidae). Freshwater biological association scientific publication No. 45.

Funakoshi, M. and Committee for the conservation of three lakes in Nishina (1983): The aim of environmental conservation in Nishina-sanko. Research Report from the committee for the conservation of three lakes in Nishina, 56-67. (in Japanese).

Hayashi, H. (ed.) (1985): Blooms of Anabaena macrospora and associated algophagous amoeba in Lake Kizaki. Res. Rep. Spec. Res.
Proj. Environ. Sci., B258-R12-7: 1-100. (in Japanese).

Hayashi, H. (1989): A change of biota in Lake Kizaki. -Proceedings of 2nd symposium on aquatic carrying capacity and its application-. Res. Rep. Nat1. Inst. Environ. Stud. Jpn., F-10-' 89: 49-58. (in Japanese).

Hayashi, H. (1990) : Remarkable changes in Lake Kizaki biological factors. Jpn. J. Limnol., 51 : 22-23

Iwakuma, T. and Yasuno, M. (1981): Chironomid populations in highly eutrophic Lake Kasumigaura., Verh. Internat. Verein. Limnol., 21: 664-674.

Iwakuma, T. Yasuno, M. Sugaya, Y. and Sasa, M. (1988): Three large species of Chironomidae (Diptera) as biological indicators of lake eutrophication., Biological monitoring of environmental pollution. Tokai Univ. Tokyo.

Jonasson, P. M. (1972) : Ecology and production of the profundal benthos in relation to phyto plankton in Lake Esrom. Oikos suppl., 14: 1 $-148$.

Kida, K., Park. H. D. and Hayashi, H. (1989) : Occurrence of fresh water red tide of Peridinium spp. in Lake Kizaki. J. Fac. Sci. Shinshu Univ., 24 : 13-25. (in Japanese).

Kitagawa, N. (1973): Studies on the bottom fauna of Lakes Kizaki-ko, Aoki-ko, Nakatsuna-ko, Nojiri-ko and Suwa-ko, Jpn. J. Limnol., 34 : 12-23. (in Japanese with English summary).

Kitagawa, N. (1974) : Studies on the bottom fauna of Lakes Tyuzenji-ko, Yuno-ko, Suge-numa and Maru-numa. Jpn. J. Limnol., 35 : 32-42 (in Japanese with English summary).

Kitagawa, N. (1978): A classification of Japanese lakes based on hypolimnetic oxgen and benthonic fauna. Jpn. J. Limnol., $39: 1-8$. (in Japanese).

Miyadi, D. (1931): Studies on the bottom fauna of Japanese lakes. 1. Lakes of Shinano Province, Jpn. J. Zool., 3 : 206-210.

Mryadi, D. (1932): Studies on the bottom fauna of Japanese lakes. 2. Mountain lakes of the tributaries of the River Tone, with special reference to azoic. Jpn. J. Zool., 3 : 259-297.

Miyadi, D. (1933): Studies on the bottom fauna of Japanese lakes. 10. Regional characteristics and a system of Japanese lakes based on the bottom fauna, Jpn. J. Zool., 4 : 417-437.

Park, H. D. and Hayashi, H. (1992) Life cycle of Peridinium bipes f. occulatum (Dinophyceae) isolated from Lake Kizaki, J. Fac. Sci, Shinshu 
Univ., 27 (2) 87-104.

SAIJO, Y: and Committee for the conservation of three lakes in Nishina (1983): The aim of environmental conservation in Nishina-sanko. Research Report from the committee for the conservation of three lakes in Nishina, 37-43. (in Japanese).

SaSA, M. (1984): Studies on chironomid midges in lakes of the Nikko National Park. Part II, Taxonomical and morphological studies on the chironomid species collected from lakes in the Nikko National Park., Res. Rep. Natl. Inst. Environ. Stud. Jpn., 70 : 19-215.

Tanaka, A. (1930) Studies on the lake of the Japanese Northern Alps. Tokyo, Kokinshyoin. (in Japanese).

Tokunaga, M. (1940) Chironomidae from Japan. XII. New or little known Ceratopogonidae and Chironomidae. Philipp. J. Sci., 72 : 255-317.

Watanabe, M., Kiyosawa, H. and Hayashi, H. (1985): Studies on the planktonic blue-green algae, 1. Anabaena macrospora KLEBAHN from Lake Kizaki. Bull. Natn. Sci. Mus., Tokyo, Ser. B, 11: 69-76. (in Japanese with English summary).

Wiederholm, T. (1983) : Chironomidae of the holarctic region keys and diagnoses. Part 1-larva. Ent. Scand. Suppl., No. 19.

Yamagishi, H. and Fukuhara, H. (1972): Vertical migration of Spaniotoma akamusi larvae (Diptera: Chironomidae) through the bottom deposits of Lake Suwa., Jap. J. Ecol., 22 : 226 $-227$.

Yasuno, M., Iwakuma, T., Sugaya, Y. and Sasa, M. (1983) : Zoobenthos of Japanese lakes of different trophic status, with special reference to Chironomidae. Res. Rep. Spec. Res. Proj. Environ. Sci., 182-R12-17 : 21-48. (in Japanese). Yasuno, M., Inakuma, T., Sugaya, Y. and Sasa, M. (1984): Studies on chironomid midges in lake of the Nikko National Park. Part I, Ecological studies on chironomids in lakes of the Nikko National Park., Res. Rep. Natl. Inst. Environ. Stud. Jpn., 70: 1-17.

(著者: 平林公男, 山梨県立女子短期大学一般教 育科， ₹ 400 山梨県甲府市飯田 5-11-1：林秀 哃, 信州大学理学部生物学教室, 7390 長野県松 本市旭 3-1-1；Kimio Hirabayashi, Liberal Arts, Yamanashi Women's College, Kofu, 400; Hidetake Hayashr, Department of Biology, Faculty of Science, Shinshu University, Matsumoto 390)

Received : 9 July 1993

Accepted : 18 December 1993 